\title{
Effectiveness of immunotherapies from oyster mushroom (Pleurotus species) in the management of immunocompromised patients
}

\author{
Oloke J. K. ${ }^{1,2}$, Adebayo E. A. ${ }^{1,3, *}$ \\ ${ }^{1}$ Department of Pure and Applied Biology, Ladoke Akintola University of Technology, P.M.B. 4000, Ogbomoso, Nigeria \\ ${ }^{2}$ Department of Microbiology \& Immunology; All Saints University; Belair, Kingstown, St Vincent \&The Grenadines \\ ${ }^{3}$ Biotechnology of Edible, Functional and Medicinal Mushrooms, Colegio de Postgraduados, Apartado Postal 129, Puela, Puebla, Mexico \\ Email address: \\ eaadebayo@lautech.edu.ng (Adebayo E. A.), brogoke2003@yahoo.com (Adebayo E. A.)
}

\section{To cite this article:}

Oloke J. K., Adebayo E. A.. Effectiveness of Immunotherapies from Oyster Mushroom (Pleurotus species) in the Management of Immunocompromised Patients. International Journal of Immunology. Special Issue: Immunotherapy. Vol. 3, No. 2-1, 2015, pp. 8-20. doi: 10.11648/j.iji.s.2015030201.12

\begin{abstract}
In the recent years, mushrooms are distinguished as important natural resources of immunotherapy which can be used as immunomodulating and immunostimulating in the management of some immunodeficiency diseases such as cancer, tumour, HIV, tuberculosis etc. Mushroom of the genus Pleurotus are good sources of several bioactive compounds which are able to augment or complement a desired immune response. Such bioactive compounds are polysaccharopeptides, polysaccharide-proteins, functional proteins (ubiquinone-9, nebrodeolysin, ubiquitin-like peptide and glycoprotein), glucans, proteoglycans and many others. Most of these bioactive compounds follow the immunomodulatory pathway mechanism of polysaccharide ( $\beta$-glucan) from mushrooms by stimulating activities for both innate and adaptive immune systems. They proliferate and activate innate immune system components such as natural killer (NK) cells, neutrophils, and macrophages, and stimulate cytokines expression and secretion. These cytokines in turn activate adaptive immunity through the promotion of Bcells for antibodies production and stimulation of T-cell differentiation to T helper (Th1 and Th2) cells, which mediate cell and humoral immunities, respectively. In this review, the immunotherapeutic potential of oyster mushroom in relation to bioactive compounds produced is shown and this suggests that the oyster mushrooms are one of the most important natural products and functional foods.
\end{abstract}

Keywords: Oyster Mushroom, Immunotherapy, Beta Glucan, Lectin, Polysaccharide

\section{Introduction}

Immunotherapy can be called biologic therapy or biotherapy, which is the treatment that activates certain parts of a patient immune system to fight diseases such as cancer, HIV, tuberculosis etc. This can be done in a couple of ways, such as stimulating the immune system of the patient to work harder or smarter to attack the disease or giving the patient immune system components, such as man-made immune system proteins[1,2]. Immunotherapy treatment can be general or specific. In the general method, the patient immune system is boosted in a general way to attack any disease, while in the specific method, the patient immune system is trained to attack a specific disease. Practices of immunotherapy, for example in treating cancer patient can be traced to William Coley in the late 1800 s, when he treated cancer patients with certain kinds of bacteria, known as Coley toxins. Since then, several studies have reported the uses of immunotherapies such as T-cell adoptive immunotherapy for lymphoblastic leukemia [2], cancer regression and autoimmunity by clonal repopulation with antitumour lymphocytes [3], therapeutic antibodies and immunologic conjugate [4], cancer regression by transferring genetically engineered lymphocytes [5], safety and tumour responses with lambrolizumab (anti-PD-1) in melanoma [6], improved survival in patients with metastatic melanoma [7] to mention a few.

Immunotherapy is a way of increasing the survival rate of immunocompromised patients. People who are suffering from different diseases like liver cirrhosis, advanced HIV/AIDS, 
cancer, recent bone marrow transplant and other severe immunodeficiency diseases [8] can be immunosuppressed and subjected to increase risks of adverse events (AEs)[9]. In immunocompromised patients, acute respiratory failure (ARF) is both common and severe[10]. ARF is the leading cause of intensive care unit (ICU) admission in patients with hematological or solid malignancies. Few years ago, studies have shown mortality rates of nearly $50 \%$ in this population[10,11,12]. Mortality rates are highest in patients with severe respiratory distress requiring invasive mechanical ventilation (IMV). In this situation, mortality can reach $40 \%$ in organ transplant recipients and patients receiving immunosuppressive treatments[13,14], and $60 \%$ in patients with hematological or solid malignancies[11,12]. Treating or incorporating the diet of these patients with natural products such as mushroom with good potential in immunomodulating activity will increase the survival rate of the patients. Mushrooms (Pleurotus species) display in vivo and in vitro immunomodulatory activity, in particular since fungal compounds exhibit antitumour activity, based on modulation of the immune system[15]. In clinical practice, immunomodulators are usually classified into immunosuppressants, immunostimulants, and immunoadjuvants.

Oyster mushroom (Pleurotus species) is commercially important in the world mushroom market, and several species are grown commercially on a large and small scale in many countries[16]. They have long been valued as tasty and nutritional foods, by different societies worldwide. Pleurotus species have been recognized as mushroom with dual functions to humans; both as food and medicine [17,18]. They are nutritive with good quantity of proteins, vitamins and minerals. Medicinally, they are been recommended for obese persons and diabetes patients because of low calorie value [17] and very low sugar without starch[19]. Several studies on various Pleurotus species have shown a number of pharmacological activities, such as anti-tumour, immunomodulatory, antigenotoxic, antioxidant, antiinflammatory, hypocholesterolaemic, antihypertensive, antiplatelet-aggregating, antihyperglycaemic, antimicrobial and antiviral activities[20,21,18,16]. Pleurotus species are good source of immunomodulators, the substances considered as "host defense potentiators" (HDPs) as judged by their immuno-stimulating properties[20]. Several molecules that are able to augment or complement a desired immune response have been isolated from Pleurotus spp., such as: water-soluble polysaccharides from $P$. citrinopileatus fermentation broth [22] glucans from $P$. florida fruiting bodies[23]; proteoglycans, polysaccharides and polysaccharopeptides from $P$. ostreatus mycelia[24,20,25]; a ubiquitin-like peptide from $P$. sajorcaju[26]; a glycoprotein from $P$. citrinopileatus [27]; a Pleurone from $P$. eryngii [28] and DNA from P. ostreatus fruiting bodies [29]. These compounds stimulate different cell populations of the immune system, for instance, macrophages, Natural killer (NK) cells, T-cells, and also modulate cytokine system[21]. The objectives of this review are the compilation of the newer achievements in the effectiveness of immuno- therapies from oyster mushrooms (Pleurotus spp.) in health management.

\section{Taxonomy of Genus Pleurotus}

Oyster mushrooms are cosmopolitan, and belong to the genus Pleurotus (Fungi: Basidiomycetes). Their cap is normally shell-like (about 5-20 cm in diameter; 1.9-7.8 inches), fleshy, with eccentric or lateral stipe; and their color can be white, cream, yellow, pink, brownish, or dark gray [30]. Oyster mushroom was first cultivated in 1917 at Germany by Flank. Evolutionary connection among species in the genus Pleurotus is still not clear and many taxonomic issues remain controversial. The genus Pleurotus is one of the most diverse groups of cultivated mushrooms. Fungal populations are established and developed through sexual and asexual reproduction [31]. Conventional methods for classification (fruit body morphology, microscopic observations, mating studies between populations, biochemical analyses) have not provided clear-cut results [30]. This taxonomic confusion has always been associated with the genus Pleurotus, especially species belonging to the $P$. ostreatus complex due to morphological variations of different specimens and similarity of isolates belonging to different species [32]. Molecular studies have shown to be more informative: intra and inter-specific heterogeneity was determined using ribosomal and mitochondrial DNA analyses, and phylogenetic studies of ribosomal DNA sequences indicated geographic speciation in several groups. Hilber [33] reported results of mating reactions as well as the microscopic and macroscopic characteristics of many Pleurotus isolates and concluded that $P$. pulmonarius and $P$. ostreatus were different species, $P$. sapidus is more likely to correspond to $P$. cornucopiae, and $P$. columbinus is simply a variety of $P$. ostreatus. There are other disagreements concerning the exact taxonomic position of the cultivar $P$. florida (considered either as a $P$. pulmonarius or a $P$. ostreatus strain) and whether $P$. cystidiosus and $P$. abalonus belong to separate species $[34,35]$ or the same species $[36,37]$.

Zervakis and Labarer [38] classified 23 isolates of genus Pleurotus with dendrogram of taxonomic distances and demonstrated the suitability of enzyme isoelectric focusing in classification, as it clearly distinguished the four well-defined species $P$. cornucopiae, $P$. cystidiosus, $P$. eryngii and $P$. flabellatus. The $P$. ostreatus, whose taxonomy is controversial, was separated from $P$. pulmonarius, and $P$. columbinus and classified as a distinct taxon. The delimitation of $P$. sajor-caju and $P$. sapidus strains appeared to be more difficult as they seemed to be closely related; the former with $P$. pulmonarius and the latter with $P$. ostreatus. Vilgalys et al. [39] identified three intersterile groups, $P$. ostreatus, $P$. pulmonarius and a new species limited to North America: P. populinus. Vilgalys et al. [40] identified 15 intersterility groups of Pleurotus (ostreatus, pulmonarius, populinus, cornucopiae, djamor, eryngii, cystidiosus, levis, dryinus, tuberregium, agaves, abieticola, brazil, australis, 
purpureo-olivaceus) of which some groups have been added in the later time. Oyster mushroom are generally classified as follow; Scientific Name:-Pleurotus spp.; Phylum:Basidiomycotina; Class:-Basidiomycetes; Sub class:Holobasidiomycetidae; Family:-Polyporaceae; Genus:Pleurotus; species:- sajor caju, sapidus, ostreatus, eous, membranaceous, florida, citrinopileatus, flabellatus, pulmonarius, geesteranus, ulmarius, tuberregium, cystidiosus, eryngii and others.

\section{Life Cycle of Pleurotus (Oyster Mushroom)}

Pleurotus mushrooms show the typical life cycle of Basidiomycetes, a major fungal group (Fig. 1a). It begins with the germination of a basidiospore in a suitable substrate, which gives rise to a monokaryotic mycelium containing genetically identical nuclei (n) and capable of indefinite independent growth. When two compatible monokaryotic mycelia are in close contact, they are able to establish a fertile dikaryon by hyphal fusion or plasmogamy. This dikaryon $(n+n)$, having clamp connections and binucleate in each hyphal compartment (Figure 1b), contains two genetically different nuclei (one from each monokaryon) throughout the mycelium [30,41]. When environmental conditions are appropriate (temperature, light, relative humidity), the dikaryotic mycelium will differentiate into fruit bodies having specialized structures called basidia. In these club-shaped, binucleate cells, which are formed in the lamellae (hymenium) of each fruit body, karyogamy (fusion of the paired nuclei; $2 \mathrm{n}$ ) and meiosis (recombination and segregation) take place. The four resulting haploid nuclei move to the sterigmata on the basidium, to form four new basidiospores. When the fruit bodies are mature, basidiospores are discharged, starting the sexual life cycle again.

\section{Production of Pleurotus Species}

Increase in consumer demand for oyster mushrooms in the world has continued its rapid pace in the last few years. The increase in demand is as result of significant role play in human health, nutrition and disease.

Since the inception of oyster mushroom cultivation by 1917 in Germany, the production kept on increasing annually. Royse[43] reported an increase of more than 18-fold in total mushroom production worldwide in the last 32 years, from about 350,000 metric tons in 1965 to about $6,160,800$ metric tons in 1997, with Pleurotus species occupy the third position, beside Agaricus and Lentinula in the first and second position respectively [44]. Annual production increases for Pleurotus spp. have averaged 14\% (from 880t in 1996 to $1940 t$ in 2002; USDA [45]. International demand for oyster mushrooms has remained steady (at about 900,000t annually) over the last decade. The People's Republic of China is the major producer and consumer of oyster mushrooms, accounting for nearly $90 \%$ of total world production[46]. The available figures have revealed that oyster mushroom production increased $44.2 \%$ during the period 1986-1991, reaching about 917,412 tons(fresh weight) in 1991. China, South Korea, Japan, and Indonesia are major producers[30]. Some years ago oyster mushrooms started to occupy the second position among cultivated edible mushrooms worldwide due to their nutritional and medicinal values [47]. In the United States, its cultivation is second only to that of the white button mushroom, Agaricus bisporus. In 1995, the United States produced $880 \mathrm{t}$ of oyster mushroom, a $94 \%$ increase over the previous year [48]. At present, Pleurotus spp. has become the second most important cultivated mushroom, accounting for about $22 \%$ of the total world production.

\section{Bioactive Compounds with Immunotherapeutic Potential from Pleurotus Species (Oyster mushroom)}

In the recent years, several bioactive compounds have been isolated from genus Pleurotus. The like of these bioactives are polysaccharides [22]; polysaccharopeptides [25]; polysaccharide-proteins[18]; functional proteins such as Pleuron [28], glycoprotein [27], ubiquinone-9[49], nebrodeolysin[50], ubiquitin-like peptide[26]; glucans [23]; proteoglycans [24] and lectin [51]. Some of these compounds act as immunotherapy by influencing the production of cytokine in human peripheral blood mononuclear cells (hPBMC), which may include mitogenicity, stimulation and activation of immune effector cells[15]. Many other compounds have potent antitumor activity by inhibition of tumor growth and induced apoptosis, while some elicited amitogenic response from murine splenocytes and inhibited HIV-1 reverse transcriptase[51,49]. Generally most of these bioactive compounds follow the immunomodulatory pathway mechanism of polysaccharide ( $\beta$-glucan) from mushrooms. Mushrooms polysaccharides immunomodulators exhibit stimulating activities for both innate and adaptive immune systems. They proliferate and activate innate immune system components such as natural killer (NK) cells, neutrophils, and macrophages, and stimulate cytokines expression and secretion[52]. These cytokines in turn activate adaptive immunity through the promotion of B -cells for antibodies production and stimulation of T-cell differentiation to $\mathrm{T}$ helper (Th1 and Th2) cells, which mediate cell and humoral immunities, respectively[53]. Based on their high molecular weight, mushroom polysaccharides are not able to penetrate the immune cells to activate immune cells directly. Thus, the stimulation mechanism of polysaccharides involves different cell receptors such as dectin-1, Complement receptor 3 (CR3), Lactosyl ceramide (LacCer), and Toll-like receptor (TLR)2. In such cases, the effectiveness of polysaccharides is governed by their binding affinity to immune cell receptors[54]. 


\subsection{Immunotherapy of Mushroom Polysaccharides from Pleurotus Species}

The polysaccharides (exopolysaccharides and endopolysaccharides) found in mushrooms belonging to the genus Pleurotus have revealed important biological activities. Polysaccharides can be isolated from the mycelium, the fruiting body, and the sclerotium, representing three different stages in the fungal life cycle. Polysaccharides differ in their primary structure (type of basic sugar), type of linkage $(\alpha, \beta$, etc.), degree of branching, and molecular weight, among other parameters. Significant biological activities reported in literature are antitumor, immunomodulatory, antioxidant, hypocholesterolaemic, antihyperglycemic, antimicrobial, antiviral activities and as vaccine adjuvants [21,55,56,57]. In particular, polysaccharides act as a defense mechanism against invasion by foreign bodies to enhance the natural immune system, including activation of macrophages and natural killer (NK) cells (Figures 2 \& 3).

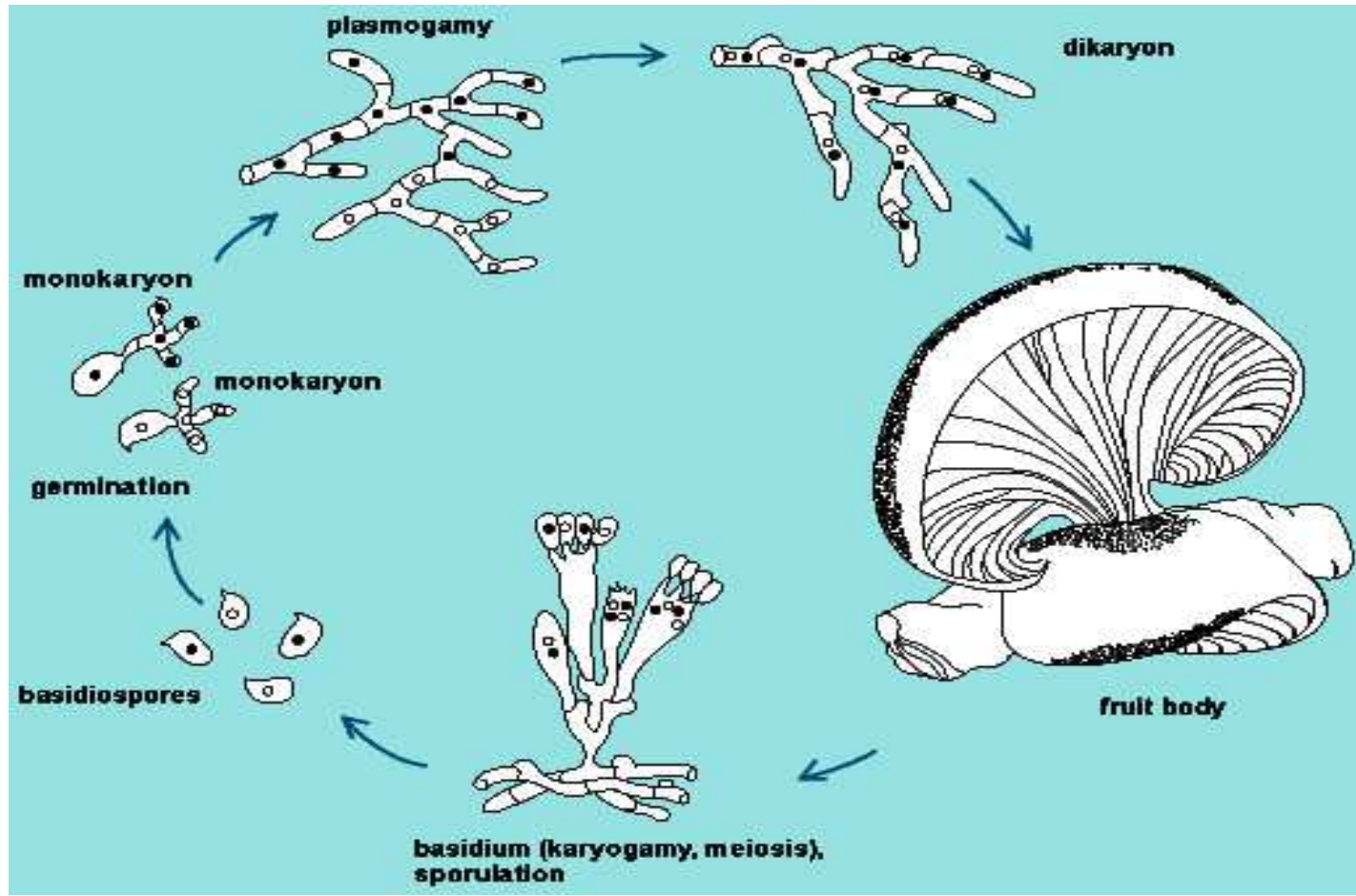

Figure 1a. Life cycle of the oyster mushroom Pleurotusostreatus Source: Adebayo and Martínez-Carrera [42]

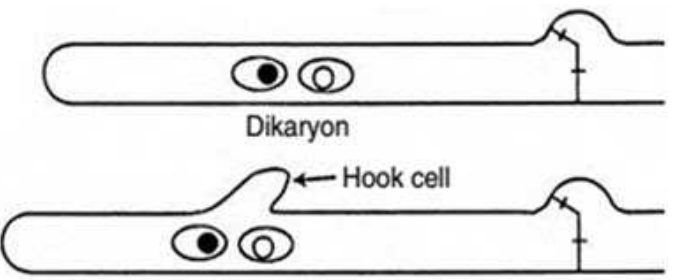

(1) Conjugate nuclear division occurs.

(2) Beginning of septal formation.

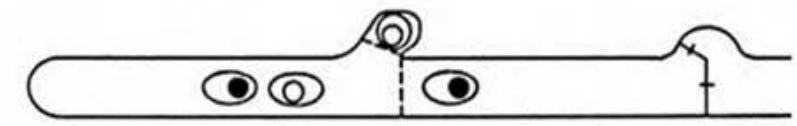

\section{(3) Septal formation completed andfusion of hook} cell with enultimate cell.

\section{(4) Passage of nucleus from hook cellinto}

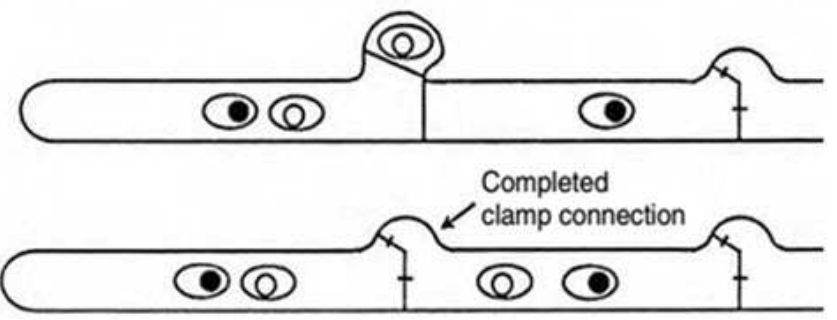
penultimate cell.

Figure 1b. Diagrammatic representation of clamp connection formation.

The defense mechanism by polysaccharide increase macrophage cytotoxic activity against tumor cells and 
microorganisms; activates phagocytic activity; increases reactive oxygen species (ROS) and nitric oxide (NO) production, and enhances secretion of cytokines and chemokines, such as tumor necrosis factor (TNF- $\alpha$ ), interleukin (IL)-1 $\beta$, IL-6, IL-8, IL-10, IL-12, IFN- $\gamma$ and IFN$\beta 2[25,58]$. Several years ago, three antitumor agents of polysaccharide nature i.e. lentinan, schizophyllan and protein-bound polysaccharide (PSK, Krestin), were isolated from Lentinula edodes, Schizophyllum commun eand Coriolus versicolor respectively and have since become large market items in Japan[59]. Lentinan and Schizophyllan are pure $\beta$-glucans $[60,61,62]$ whereas PSK is a protein-bound $\beta$ glucan $[63,64]$. A polysaccharopeptide (PSP) has also been isolated from a strain of Coriolus versicolor in China and become widely used in clinical treatments as an anti-cancer and immunomodulatory agent[65]. PSP manufactured in China is found to be quite similar to PSK in Japan.

Polysaccharide extracts from mycelium and fruit bodies of $P$. pulmonarius exerted a direct antiproliferative effect on cancer cells expressing high galectin-3 concentrations and concomitantly down-regulated the adherence of colon cancer cell lines (HT29, HCT-116), which directly interfere with cancer progression and metastasis[66]. Polysaccharide which contain both $\alpha$ and $\beta$ linkages obtained from $P$. pulmonarius showed a potent anti-inflammatory effects against carrageenan and formalin-induced paw edema in rats with higher inhibitory percentage in rats writhing; $83.33 \%$ and $92.37 \%$ inhibition obtained in carrageenan and formalininduced respectively[18]. Addition of polysaccharide from $P$. pulmonarius into the diet of 4 -week old mice containing a carcinogen; Diethylnitrosoamine (DENA) delayed progression of carcinogenesis (67).

Acetone extract from $P$. pulmonarius and $P$. ostreatus exhibited a profound anticancer potential as they offered protection to animals as tumour suppressor [68]. Refaie et al. [25] reported that the intraperitoneal administration of polysaccharopeptides from $P$. ostreatus mycelium at dose " 25 $\mathrm{mg} / \mathrm{kg}$ ", thrice weekly, for five consecutive weeks elevated dramatically serum IFN- $\alpha$ level in adult female Swiss albino mice. The water-soluble polysaccharide (POP) with a molecular mass of $2.4 \times 10^{4} \mathrm{Da}$, obtained from the fruiting body of $P$. ostreatus, enhance concanavalin A (ConA)- or induced lymphocyte proliferation on male mice[69].

Polysaccharides from hot water extract of $P$. geesteranus showed significant cytotoxicity in human breast cancer cell line MCF-7[70]. Water-soluble polysaccharides extracted from $P$. citrinopileatus fermentation broth have been shown to reduce the number of metastatic tumour nodules in tumour-bearing mice [22]. The protein-polysaccharide from $P$. ostreatus and P. sajor-caju inhibited the growth of a solid Sarcoma 180 tumor implanted in mice[71]. In addition, the hot water extracts of $P$. sajor-caju and $P$. pulmonarius inhibited HIV-1 reverse transcriptase activity [72]. Similar activity was also observed by Choi et al. [73] with hot water and ethanol extracts from fruiting body of oyster mushroom that exerted positive effect on three human solid carcinomas, (A549) and two cervical carcinomas (SiHa and HeLa). Their report showed that ethanol extracts of Pleurotus species had high antitumor activity towards lung cancer cells (A549). Morris et al. [20] reported that Pleurotus powder and hot water extract polysaccharides obtained from fruit body, administered orally to cyclophosphamide-treated mice, provides immunological benefits in terms of the recovery of bone marrow cellularity, increase of white blood cell counts, and stimulation of cell-mediated immune responses. Major component behind the anticancer activity of Pleurotus mushrooms is its polysaccharide fraction called pleuran, a member of polysaccharide beta glucans, which is an important constituent of Pleurotus species.

\subsection{B-Glucan as Immunotherapy from Pleurotus Species}

The major medicinal effects of mushrooms, i.e., immunity potentiation and antitumor activities, are attributed to $\beta$ glucans. $\beta$-glucans from various fungi are not digested by human enzymes when orally administered, but instead are taken up in the small intestine, which stimulates mucosal and systemic immunity [74]. Uptake of $\beta$-glucans stimulates antitumor activities as well as protective activities against fungal and bacterial infections in animals and human. Despite their high molecular weight, $\beta$-glucans, when orally administered, are absorbed in the intestine and activate innate and adaptive immunities[75].

$\beta$-glucans consist of a backbone of glucose residues usually joined by $\beta-(1-3)$ linkages, to which glucose sidechain residues are often attached [76,77]. In some fungi $\beta$ glucans, no side-chain substitution occurs, as with the bacterial $\beta$-glucan, curdlan, which contains only $\beta$-(1-3)glucosidic linkages [77]. No un-branched $\beta-(1-3)$ or $\beta-(1-6)$ fungal $\beta$-glucans are known, although the extent of the sidechain substitutions can vary considerably [76]. Among the various $\beta$-(1-3), $\beta-(1-4)$ and $\beta-(1-6) \beta$-glucan linkages, only $\beta-(1-3)$ stimulates immunity and shows antitumor activities[75]. About half the mass of the fungal cell wall consists of $\beta$-glucans $[78,79,77]$, with many of them excreted into the growth medium, making their recovery, purification and chemical characterization much simpler[78,76] and they are referred to as extracellular metabolite . $\beta$-glucans homeostasis is maintained by $\beta$-glucan synthases and $\beta-(1-3)$ or $\beta$-(1-6)-glucanase activities [80,81]. Some fungal $\beta$ glucans that markedly stimulate the immune system, offer protection from attack by pathogenic microbes and from harmful effects of environmental toxins and carcinogens $[82,83]$. $\beta$-glucans are not synthesized by humans, so these compounds are recognized as non-self-molecules, inducing both innate and adaptive immune responses[83]. They appear to activate phagocytes, thus leading to elimination of pathogens by phagocytosis [84,85]. Among these, the macrophages preferentially attack dead cells and intracellular pathogens [86]. Natural killer cells (NKs) circulate in blood to lyse cancer and virus-infected cells, whereas neutrophils are effective against pyogenic bacteria. Some $\beta$-glucans activates type 3 complement receptors (CR3), which coat bacterial cells to facilitate their engulfment by phagocytes $[87,82]$. 
Many $\beta$-glucans stimulate macrophages to produce cytokines, local immunomodulators, and these in turn activate adaptive immunity[85,88,89], which can then stimulate the activity of cytokines such as interleukin (IL)-2, IL-10 andIL-12 (Figure 2) [90,91].

\section{Cytokine/Chemokine \\ Production}

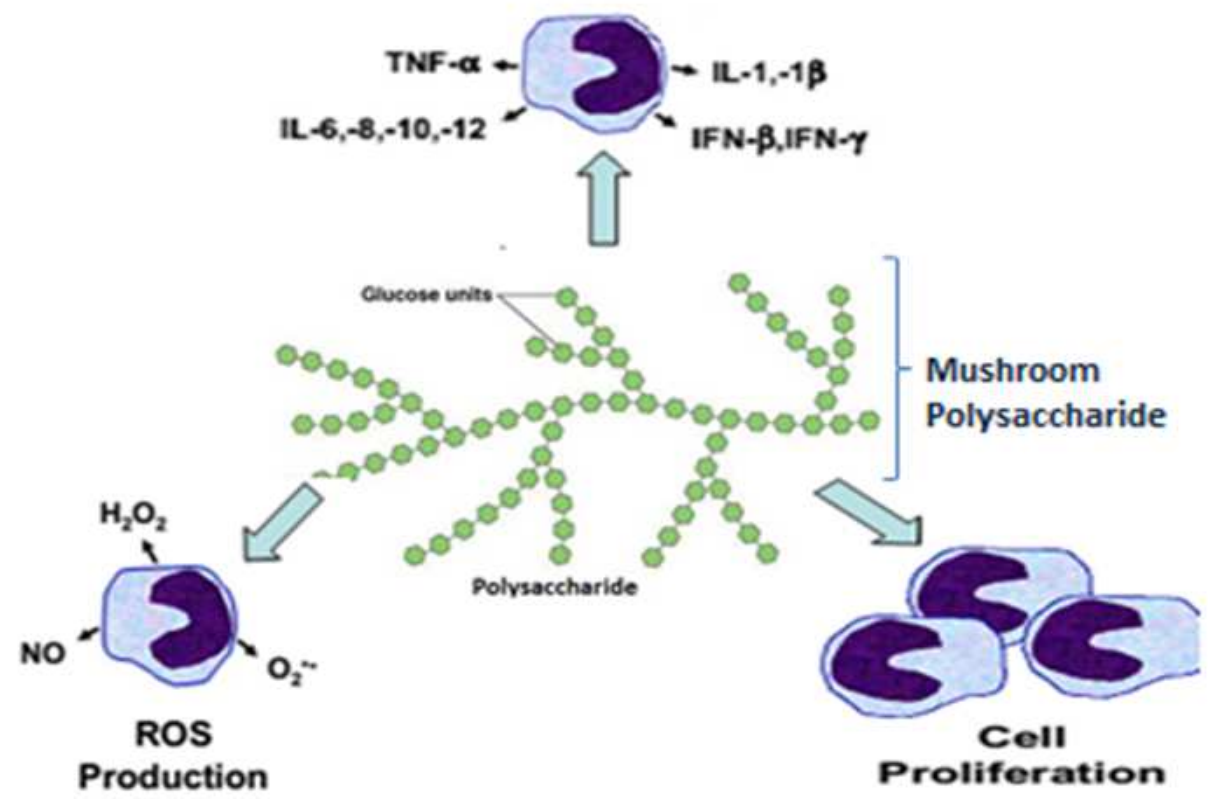

Figure 2. Activation of macrophage host defense responses by mushroom polysaccharides. IL= interleukin; IFN=interferon; TNF- $\alpha=$ tumor necrosis factor $\alpha$; $N O=$ nitric oxide; $R O S=$ reactive oxygen species. Source Refaie et al (25).

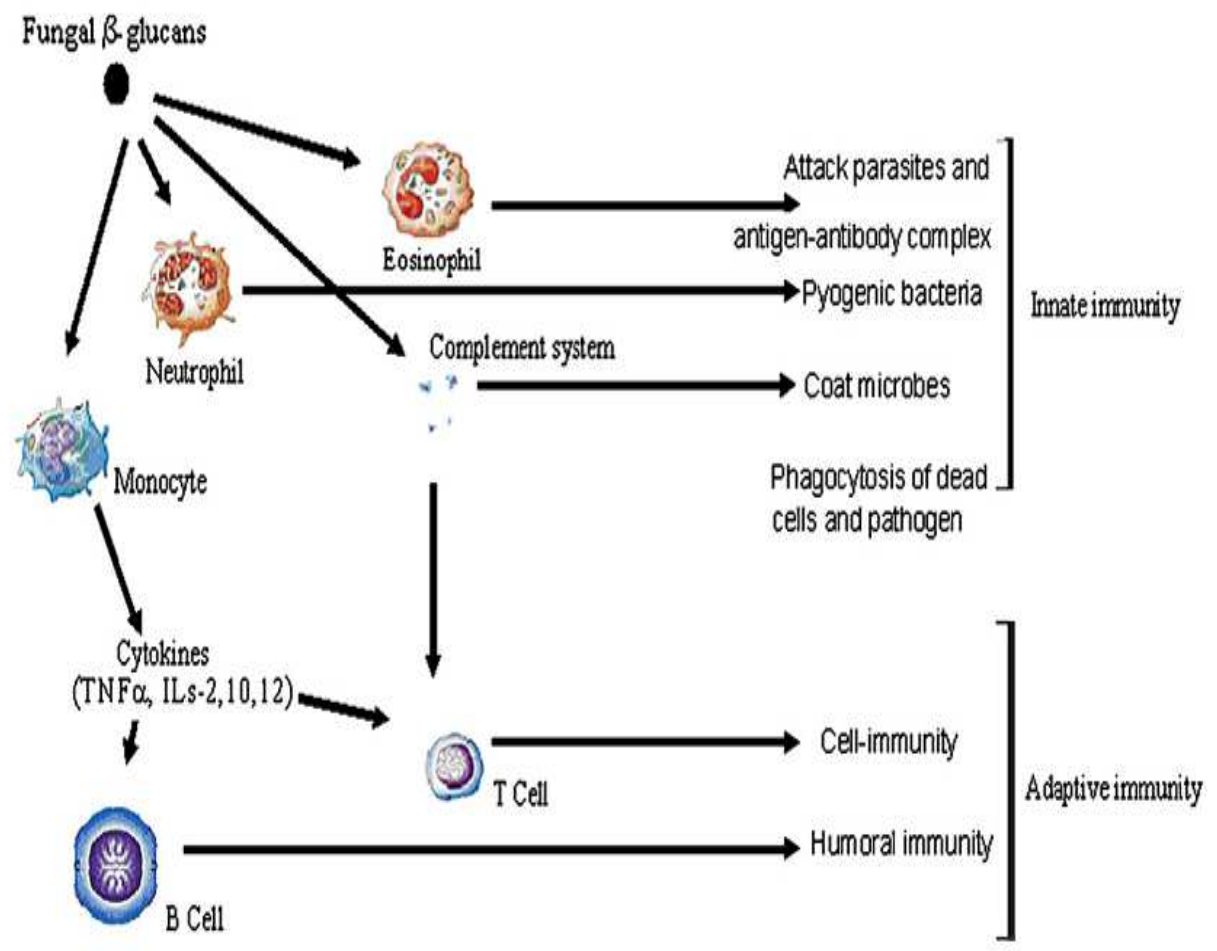

Figure 3. Immunostimulation pathway by fungal $\beta$-glucans.

Sources: Chen and Seviour, [54]

$\beta$-Glucans of the $P$. tuber-regium, when sulfated, showed an antitumor effect and antiviral activity[92]. Manzi and 
Pizzoferrato [93] reported water-soluble and water-insoluble $\beta$-glucans from $P$. ostreatus, $P$. eryngii and $P$. pulmonarius that have pronounced effect on humans and animals immune systems. $\beta$-glucan with (1-3) and (1-6) linkage, produced by $P$. ostreatus was reported to show strong anti-respiratory infection [94] and activation of natural killer cell (NKs)[95] at clinical trial. The $\beta-((1-3 / 1-6)-\mathrm{D}$-glucan isolated from $P$. ostreatus decreased the arthritis development in rats [96]. Jedinak et al. [97] reported that $\beta$-glucan from $P$. pulmonarius suppressed lipopolysacharide (LPS)-induced secretion of tumor necrosis factor- $\alpha(\mathrm{TNF}-\alpha)$, interleukin- 6 (IL-6), and IL-12p40 from RAW264.7 macrophages. Beta glucan from $P$. pulmonarius inhibited (LPS)-induced production of prostaglandin E2 (PGE2) and nitricoxide (NO) through the down-regulation of expression of COX-2 and iNOS, respectively. $\beta$-glucan also inhibited LPS dependent DNA-binding activity of AP-1 and NF-қB in RAW264.7 cells[97]. Oral administration of $\beta$-glucan markedly suppressed secretion of TNF- $\alpha$ and IL- 6 in mice challenged with LPS in vivo. Anti-inflammatory activity of $\beta$-glucan was confirmed by the inhibition of proliferation and secretion of interferon- $\gamma$ (IFN- $\gamma$ ), IL-2, and IL-6 from concanavalin A(ConA)-stimulated mouse splenocytes[97]. Glucans isolated from $P$. florida fruiting bodies activated the phagocytic response of mouse macrophages in vitro [98] and significantly induced the proliferative response as well as phagocytic activity of fish leukocytes in vitro[99]. Moreover, Zhang et al.[100] demonstrated that, in contrast to waterinsoluble $\beta$-glucans isolated from $P$. tuber-regium sclerotia, their corresponding water-soluble sulphated derivatives exerts antiviral activities against herpes simplex virus type land type 2 . The effect is presumably elicited by the binding of sulphated $\beta$-glucans to viral particles, thus preventing them from infecting the host cells.

\subsection{Functional Proteins as Immunotherapy from Pleurotus Species}

The ability of fungal compounds, like fungal immunomodulatory proteins (FIPs), to alter the cytokine response has been described [101]. Hsu et al.[102] reported the purification of FIP-Vvo and suggested that the immunomodulatory effects might be due to cytokine regulation of human peripheral blood mononuclear cells (hPBMC). FIPs are classified into a distinct family since they are a group of fungal proteins defined by amino acid sequence similarity and their actions on immunological responses [103,104].

Pleurotus have beeen shown to secret high levels of proteins and novel enzyme variants, with desirable properties for medicinal and biotechnological applications[105]. A functional protein (PCP-3A)was isolated from the fresh fruit bodies of $P$. citrinopileatus, which inhibited the proliferation of human leukemia cell U937. Flow cytometry analysis revealed that PCP-3A is capable of inhibiting the growth of U937 cells and initiates apoptotic induction[106]. A novel hemolysin was isolated from $P$. nebrodensis, which showed strong cytotoxicity against Lu-04 (lung cancer), Bre-04 (breast cancer), HepG2(liver cancer), L929 (mouse fibroflast), and HeLa cells (cervical cancer) (50). This hemolysin also induced apoptosis in L929 and HeLa cells possesses anti-HIV-1 activity [50]. The protein extracts from $P$. ostreatus exhibited therapeutic efficacy against human colorectal adenocarcinoma cells and human monocytic leukemia cells by induced reactive oxygen species (ROS) production, glutathione (GSH) depletion and mitochondrial trans-membrane potential loss in SW480 cells[107].

Ribonucleases with molecular weight of $10.7 \mathrm{kDa}$ have been isolated and characterized from the P. ostreatus with the potential of neutralizing HIV through degradation of viral genetic material[108].

Laccase $(66-\mathrm{kDa})$ with an $\mathrm{N}$-terminal sequence different from those of other mushroom laccases, from fresh fruit bodies of $P$. cornucopiae, which inhibited the proliferation of murine leukemia cell line L1210 and human hepatoma cell line HepG2 has been reported (109). It also reduced the activity of $\mathrm{HIV}-1$ reverse transcriptase with an $\mathrm{IC}_{50}$ of 22 $\mu \mathrm{M}[109]$.

Bae et al. [49] demonstrated that ubiquinone-9 from $P$. eryngii inhibited mammalian topoisomerase I activity and induced apoptotic cell death of human cancer cells, but not that of normal fibroblast NIH3T3 and 3Y1 cells. An amorphous white powder with different spectral characteristics designated 'pleurone' (4H-1,3-dioxine-2,4dione) from $P$. eryngii, exhibited inhibitory activity on human neutrophil elastase (HNE) and might be beneficial for the prevention or treatment of skin aging[28]. The inhibitory mechanism of pleurone on $\mathrm{HNE}$ is a mixed-type, a combination of noncompetitive and uncompetitive inhibition against HNE. Although pleurone activity has a relatively low HNE-inhibitory activity compared with epigallocate chingallate, it might be more useful as a new HNE inhibitor due to its relatively high water solubility and low molecular weight [28]. A ubiquitin-like peptide with $9.5 \mathrm{kDa}$ and Nterminal sequence extracted from $P$. sajor-caju inhibited cellfree translation with an $\mathrm{IC}_{50}$ of $30 \mathrm{nM}$ and exhibited a ribonuclease activity of $450 \mathrm{U} / \mathrm{mg}$ toward yeast tRNA [26].

RNase (mol. wt. $14.5 \mathrm{kDa}$ ) was identified from sclerotia of $P$. tuber-regium, exhibited very stable nuclease activity at $100^{\circ} \mathrm{C}$ for $30 \mathrm{~min}$. with a higher ribonucleolytic activity toward Poly-G[110]. Another ribonuclease, pleuturegin, was also isolated from both fresh and dried sclerotia of $P$. tuberregium [111]. Similarly a protein contained in hot water extracts of $P$. pulmonarius with molecular weight of $4.5 \mathrm{kDa}$ inhibited HIV-1 reverse transcriptase activity [112]. Maiti et al. [113] assessed the antiproliferative and immunomodulatory properties of a protein fraction, named as Cibacron blue affinity eluted protein (CBAEP), isolated from $P$. florida. The results showed that the isolated protein fraction excreted a stimulatory effect on splenocytes, thymocytes and bone marrow cells. It enhanced the cytotoxicity of mouse natural killer (NK) cells and stimulated macrophages to produce nitric oxide (NO). Moreover, it displayed antiproliferative activity on several tumor cell lines by apoptosis induction. 


\subsection{Lectin as Immunotherapy from Pleurotus Species}

Lectins form a diverse group of carbohydrate-binding proteins with specific binding capacities. Lectins are abundant in vegetables, fruits, beans and mushrooms[110,114,115]. However, those derived from mushrooms have been found to possess the following attributes:- immunomodulatory[116], antiproliferative[52], antitumor[117], HIV-1 reverse transcriptase inhibiting[111], cell growth regulating[118], macrophage and lymphocyte activating $[119,120]$ and many more. Lectin purified from $P$. ostreatus (POL) acted as immunogenicity of Hepatitis B Virus (HBV) DNA vaccine, when used as adjuvant [56]. It was demonstrated that low dose of POL ( $1 \mu \mathrm{g} /$ mouse) in conjunction with HBVDNA vaccine stimulated stronger $\mathrm{HBV}$-specific delayed-type hypersensitivity (DTH) responses and higher HBV-specific IgG level than that in high dose of POL groups ( $5 \mu \mathrm{g} / \mathrm{mouse}$ and $10 \mu \mathrm{g} / \mathrm{mouse})$. POL activated strong Th2 and Th1 cell responses in immunized C57BL/6 and HBVsAg-Tg mice. POL as adjuvant of HBVDNA vaccine effectively enhanced HBV surface protein antibody (HBVsAb) [56].

A dimeric lectin, composed of subunits with a molecular weight of 40 and $41 \mathrm{kDa}$, respectively, and demonstrating similarity in N-terminal sequence to each other and to Aleuria aurantia lectin, was isolated from fresh fruiting bodies of $P$. ostreatus [117]. The lectin exerted potent antitumor activity in mice bearing sarcoma S-180 and hepatoma H-22. Survival in these mice was prolonged and body weight increase reduced after lectin treatment[117].

A novel lectin from $P$. citrinopileatus exerted potent antitumor activity in mice bearing sarcoma180, and caused approximately $80 \%$ inhibition of tumor growth when administered intraperitonealy at $5 \mathrm{mg} / \mathrm{kg}$ daily for 20 days[51]. It elicited amitogenic response from murine splenocytes in vitro with the maximal response at a lectin concentration of $2 \mu \mathrm{M}$. The lectin inhibited HIV-1 reverse transcriptase with an $\mathrm{IC}_{50}$ of $0.93 \mu \mathrm{M}[51]$. Lectin produced from $P$. florida has capability of modulating arsenic mediated toxic effects and ameliorating them. This was done by restoration of alterations in the antioxidant enzymes, oxidative stress intermediates and superoxide dismutase $\left(\mathrm{SOD}_{2}\right)$ gene expression profile on arsenic exposure[121].

\subsection{Proteoglycans as Immunotherapy from Pleurotus Species}

Proteoglycans are group of glyco-conjugates with a special class of glycoproteins that are heavily glycosylated. They consist of a core protein with one or more coavalently attached glycosaminoglycan chain(s). Glycosaminoglycan molecules are long unbranched polysaccharides containing a repeating disaccharide unit. Proteoglycans are remarkable for their diversity which include different cores, different numbers of glycosaminoglycans with various lengths and compositions. Many macrofungi have been reported as good producer of proteoglycan with immunomodulating activity. Such fungi are Ganoderma lucidum, Grifola frondosa,

\section{Lentinula edodes, Pleurotus ostreatus [122,24].}

Water-soluble proteoglycan fractions from $P$. ostreatus mycelia with immunomodulators and anticancer activity were reported [24]. They were tested for in vitro and in vivo immunomodulatory and anticancer effects on Sarcoma180 bearing mouse model. In vivo injection of proteoglycans to Sarcoma180 bearing mice decreased the number of tumor cells. These proteoglycans also elevated mouse natural killer cell cytotoxicity and stimulated macrophages to produce nitric oxide [24].

\subsection{Other Immunotherapy Substances from Pleurotus Species}

The genus Pleurotus produced many other bioactive substances that are of medicinal importance. Such compounds include dietary fiber, terpenoids, steroids, phenols, flavonoid, alkaloids, saponins, phlobatannins and anthraquinones[16,123]. A steroid which is the glycosylated form of ergosterol peroxide from the methanol extract of mushroom was found to be an inhibitor of proliferation of tumor cell lines $(123 ; 124)$.

An extract was obtained from $P$. ostreatus which suppressed proliferation of breast cancer (MCF-7, MDAMB-231) and colon cancer (HT-29, HCT-116) cells, without affecting proliferation of epithelial mammary MCF-10A and normal colon FHC cells[125]. Flow cytometry revealed that the inhibition of cell proliferation by $P$. ostreatus was associated with the cell cycle arrest at G0/G1 phase in MCF7 and HT-29 cells.

In yet another experiment hot water extracts of $P$. ostreatus was incubated for $24 \mathrm{~h}$ with MCF-7 cells. Cellular proliferation determined by bromodeoxyuridine incorporation was significantly $(\mathrm{P}<0.05)$ reduced up to $33 \%$ by the extract[126]. Also the extract of P. ostreatus (PO) has chemo preventive effect on inflammation-associated colon carcinogenesis induced by 2-amino-1-methyl-6phenylimidazo[4,5-b]pyridine (PhIP) promoted by dextran sodium sulfate(DSS) (127). The extract treatment at doses (100 and $500 \mathrm{mg} / \mathrm{kg}$ ), significantly reduced by 50 and $78 \%$ the number of aberrant crypt foci and the multiplicity of colon neoplasms by 43 and $89 \%$, respectively, and reduced the incidence of colon tumors and high grade dysplasia by 50 and $63 \%$ only in the dose $500 \mathrm{mg} / \mathrm{kg}$ [127].

A water-soluble extract (POE) prepared from the fresh $P$. ostreatus produced the most significant cytotoxicity on PC-3 cells (128). At the same time, POE induced a rapid apoptosis on PC-3 cells detected with annexin V-fluorescein isothiocyanate flow cytometry when the cells were exposed to POE $(150 \mathrm{~g} / \mathrm{mL})$ for 2 hours. Induced apoptosis was also confirmed by DNA fragment terminal deoxynucleotidyl transferase-mediated by X-dUTP nick end labeling staining, while POE $(200 \mathrm{~g} / \mathrm{mL})$ was added to PC-3 cells for 6 hours[128].

Methanol extracts of $P$. ostreatus and $P$. salmoneostramineus showed suppressive effect against growth of HT-29 cell line with survival rates of 39.9 and $40.7 \%$ at the concentration $500 \mu \mathrm{g} / \mathrm{ml}$, while survival rate was more 
than $50 \%$ when $P$. cornucopiae methanol extract was employed [129].

Acetone extracts of $P$. cornucopiae fruiting body completely inhibited growth and induced apoptosis of HL60 cells at a concentration $10.7 \mu \mathrm{g} / \mathrm{ml}[130]$.

Cerevisterol (CE) and ergosta-4,6,8(14),22-tetraen-3-one (EG) were purified and identified from P. tuber-regium; and tested for anti-inflammatory effects on RAW 264.7 macrophages (131). Both CE and EG inhibited the production of NO, TNF- $\alpha$, and $\mathrm{PGE}_{2}$ in LPS-treated RAW 264.7 cells. The expression of the iNOS and COX2 proteins was inhibited by CE and EG in a dose-dependent manner. In addition, $\mathrm{CE}$ and $\mathrm{EG}$ repressed the expression of iNOS, COX2, TNF- $\alpha$, andSOCS3 mRNAs[131].

\section{Conclusion}

Immune system is the body's ultimate defense against infectious diseases, tumor, immunodeficiency diseases and cancer growth. The immune system is a complex containing many interacting blood cells, protein and chemicals. A healthy immune system contains elements that are in balance with one another but in a compromised immune system, the components are unbalanced and unable to protect the body against harmful agents or processes. As shown in the review, oyster mushroom (Pleurotus species) contain a number of bioactive components such as polysaccharopeptides, polysaccharide-proteins, functional proteins, glycoprotein, glucans, proteoglycans and others. Oyster mushroom can be consumed directly as food or the extract in the diet can be used to promote health. The potential immunotherapeutic implications of oyster mushroom are enormous but, detailed mechanisms or pathways of the various health benefits of mushrooms to humans still require intensive investigation, especially with the emergence of new evidence of their health benefit effects. The exploration of newly cultivated oyster mushroom and isolation of their bioactive ingredients with mechanism and pathway based potential immunotherapeutic value remains a challenge and hence mushrooms, especially Pleurotus spp. will keep on to be the foremost spotlight of research in the upcoming prospect as well.

\section{References}

[1] American Cancer Society, Cancer Immunotherapy. Medical Rev 2014; p. 19.

[2] FryTJ, MackallCL, T-cell adoptive immunotherapy for acute lymphoblastic leukemia. AmSoc Hematol Educ Program 2013;348-353.

[3] Dudley ME, Wunderlich JR, Robbins PF, et al. Cancer regression and autoimmunity inpatients after clonal repopulation with antitumor lymphocytes. Science 2002;298:850-854.

[4] Cheung NV. Chapter 32: Therapeutic antibodies and immunologic conjugates. In: Niederhuber JE, Armitage JO,
Doroshow JH, Kastan MB, Tepper JE, eds. Abeloff's Clinical Oncology. 5th ed. Philadelphia, Pa: Elsevier; 2014.

[5] Morgan RA, Dudley ME, Wunderlich JR, et al. Cancer regression in patients after transfer of genetically engineered lymphocytes. Science 2006;314:126-129.

[6] Hamid O, Robert C, Daud A, et al. Safety and tumor responses with lambrolizumab (antiPD1) in melanoma. N Engl J Med 2013;369:134-144.

[7] Hodi FS, O’Day SJ, McDermott DF, et al. Improved survival with ipilimumab in patients with metastatic melanoma. $\mathrm{N}$ Engl J Med 2010;363:711-723.

[8] BakkenJS, BorodyT, Brandt LJ et al. Treating Clostridium difficile infection with fecal microbiota transplantation . Clin Gastroenterol Hepatol 2011; $9: 1044$ - 1049.

[9] Colleen RK, Chioma I, Monika Fet al. Fecal Microbiota Transplant for Treatment of Clostridium difficile Infection in Immunocompromised Patients. The Amer J Gastroenterology 2014; 109: 1065-1071.

[10] Azoulay E, Thiéry G, Chevret S, Moreau D, Darmon M, Bergeron A, Yang K, Meignin V, Ciroldi M, Le Gall JR, Tazi A, Schlemmer B.The prognosis ofacute respiratory failure in critically ill cancer patients. Medicine (Baltimore) 2004; 83:360-370.

[11] Thiéry G, Azoulay E, Darmon M, Ciroldi M, De Miranda S, Lévy V, Fieux F, Moreau D, Le Gall JR, Schlemmer B.Outcome of cancer patients considered for intensive care unit admission: a hospital-wide prospective study.J Clin Oncol $2005 ; 23: 4406-4413$.

[12] Benoit DD, Vandewoude KH, Decruyenaere JM, Hoste EA, Colardyn FA. Outcome and early prognostic indicators in patients with a hematological malignancy admitted to the intensive care unit for a life-threatening complication.Crit Care Med 2003; 31:104-112.

[13] Canet E, Osman D, Lambert J, Guitton C, Heng AE, Argaud L, Klouche K,Mourad G, Legendre C, Timsit JF, Rondeau E, Hourmant M, Durrbach A,Glotz D, Souweine B, Schlemmer B, Azoulay E. Acute respiratory failure in kidney transplant recipients: a multicenter study.Crit Care 2011; 15:R91.

[14] Lemiale V, Lambert J, Canet E, Mokart D, Pène F, Rabbat A, Kouatchet A,Vincent F, Bruneel F, Gruson D, Chevret S, Azoulay E:A Groupe deRecherche Respiratoire en Réanimation Onco-Hématologique Study. Identifying cancer patients with acute respiratory failure at high risk forintubation and mechanical ventilation.Respir Care2014, doi:10.4187/respcare. 02693 .

[15] Jeurink PV, Cristina LN, Huub FJS, Harry J W. Immunomodulatory capacity of fungal proteins on thecytokine production of human peripheralblood mononuclear cells. Int Immunopharmacol2008; 8: 1124-1133.

[16] Adebayo EA, Oloke JK, Ayandele AA, Adegunlola CO. Phytochemical, antioxidant and antimicrobial assay of mushroom metabolite from Pleurotus pulmonarius -LAU 09 (JF736658). J Microbiol Biotech Res 2012b; 2 (2):366-374.

[17] Chang ST, Buswell JA. Medicinal mushrooms as prominent source of nutriceuticals for the 21 st century. Curr Topics in Nutraceut Res 2003; 1: 257-280. 
[18] Adebayo EA, Oloke JK, Majolagbe ON, Ajani RA, Bora TC. Antimicrobial and anti-inflammatory potential of polysaccharide from Pleurotus pulmonarius LAU 09.Afr J Microbiol Res (2012c); 6(13): 3315-3323.

[19] Adebayo EA, Oloke JK, Azeez MA, Omomowo IO, Bora TC. Assessment of the genetic diversity among ten genotypes of Pleurotus (oyster mushroom) using nutrient and mineral compositions. Sci Horticult2014a; 166: 59-64.

[20] Morris HJ, Llauradó G, Gutiérrez A, Lebeque Y, Fontaine R, Beltrán Y, García N, Bermúdez RC, Gaime-Perraud I. Immunomodulating properties of Pleurotus sp. Fruiting bodies powder on cyclophosphamide treated mice. Pro $7^{\text {th }}$ Int Conf Mushr Biol MushrProd 2011; 324-333.

[21] Gregori A, Mirjan S, Jure P.(2007). Cultivation techniques and medicinal properties of Pleurotus spp.Food Technol. Biotechnol. 45:238-249.

[22] Wang JC, $\mathrm{Hu} \mathrm{SH}$, Liang ZC, Yeh C J .Optimization for the production of water-soluble polysaccharide from Pleurotus citrinopileatus in submerged culture and its antitumor effect. Appl Microbiol Biotechnol 2005; 67: 759-766.

[23] Rout D, Mondal S, Chakraborty I, Pramanik M, Islam SS.Chemical analysis of a new $(1 \rightarrow 3)-,(1 \rightarrow 6)$-branched glucan from anedible mushroom Pleurotus florida. Carbohydr Res 2005; 340:2533-2539.

[24] Sarangi I, Ghosh D, Bhutia SK, Mallick SK, MaitiTK. Antitumor and immunomodulating effects of Pleurotus ostreatus mycelia-derived proteoglycans. Int Immunopharmacol 2006; 6:1287-1297.

[25] Refaie FM,Esmat AY, Daba AS, Taha SM. Characterization of polysaccharopeptides from Pleurotus ostreatus mycelium: assessment of toxicity and immunomodulation in vivo. Micol Apl Int 2009; 21:67-75.

[26] $\mathrm{Ng}$ TB, Lam SK, Chan SY.A ubiquitin-like peptide from the mushroomPleurotus sajor-cajuexhibitsrelatively potent translation-inhibitory and ribonuclease activities. Peptides 2002; 23: 1361-1365

[27] Wu G, Bazer FW, Davis TA, Kim SW, Li P, Rhoads JM, Satterfield MC, Smith SB, Spencer TE. Arginine metabolism and nutrition in growth, health and disease. Amino Acids 2009; $37: 153-68$.

[28] Lee I-S, Ryoo I-J, Kwon K-Y, Ahn JS, Yoo I-D. Pleurone, a novel human neutrophil elastase inhibitor from the fruiting bodies of the mushroom Pleurotus eryngiivar. ferulae. The J Antibiot 2011; 64: 587-589.

[29] Shlyakhovenko V et al. Application of DNA from mushroom Pleurotus ostreatus for cancer biotherapy. a pilot study. Experim Oncol 2006; 28:132-135.

[30] Martínez-Carrera D. Oyster mushrooms. McGraw-Hill Yearbook of Science and Technology. Ed.: M. D. Licker. McGraw-Hill, Inc.,New York. Pp. 242-245. ISBN 0-07052625-7 (447 pp.)[http://books.mcgraw-hill.com],1999.

[31] Cohen R, Persky L, Hadar Y. Biotechnological applications and potential of wood-degrading mushrooms of the genus Pleurotus. Appl Microbiol Biotechnol 2002; 58:582-594.

[32] Asef MR. Intersterility groups of Pleurotus ostreatus complex in Iran. An Inter J Fungal Biol (2012); 3(2): 147-152.

[33] Hilber O. Die Gattung Pleurotus. Biblioth Mycolog 1982; 87:
448.

[34] Han Yh, Chbn KM, Cheno S. Characteristics and cultivation of a new Pleurotusin Taiwan. Mushr Sci 1974; 9: 167-174.

[35] Bresinsky A, Fischer M, Mbixner B, Paulus W. Speciation in Pleurotus. Mycolog 1987; 79: 234-245.

[36] Jong SC, Peng JT. Identity and cultivation of a new commercial mushroom in Taiwan. Mycolog 1975; 67: 12351238 .

[37] Moore RT. Mating type factors in Pleurotus cystidiosus. Transactions of the British Mycolog Society 1985; 85: 354358 .

[38] Zervakis G, Labarer J. Taxonomic relationships within the fungal genus Pleurotus as determined by isoelectric focusing analysis of enzyme patterns. J Gen Microbiol1992; 138: 635645 .

[39] Vilgalys R, Smith A, Sun BL, Miller OK. Intersterility groups in the Pleurotus ostreatus complex from the continental United States and adjacent Canada. Canadian J Botany 1993; 71: 113-128.

[40] Vilgalys R, Moncalvo JM, Liou SR, Volovcek M. Recent advances in molecular systematics of the genus Pleurotus. In Mushroom Biology and Mushroom Products, pp. 91-102. Edited by D. J. Royse. Penn State: Penn State University, 1996.

[41] Adebayo EA, Oloke JK, Yadav A, Barooah A, Bora TC. Improving yield performance of Pleurotus pulmonarius through hyphal anastomosis fusion of dikaryons. World J Microbiol Biotechnol 2013; 29:1029-1037.

[42] Adebayo EA, Martínez-Carrera D. Oyster mushrooms (Pleurotus) are useful for utilizing lignocellulosic biomass. Afr J Biotech 2014; (in press).

[43] Royse DJ. Cultivation of oyster mushrooms.College of Agricultural Sciences, Pennsylvania State University, University Park. PA. p. 12, 2003.

[44] Chang ST. World production of cultivated edible and medicinal mushrooms in 1997 With emphasis on Lentinus edodes (Berk.) Sing. in China. Intl J Med Mushr 1999; 1:291300 .

[45] United States Department of Agriculture, Office of Communications. Agriculture Fact Book

[46] 2002; p.169.

[47] Royse DJ, Rhodes TW, Ohga S, Sanchez JE. Yield, mushroom size and time to production of Pleurotus cornucopiae (oyster mushroom) grown on switch grass substrate spawned and supplemented at various rates. Bioresour Technol 2004; 91: 85-91.

[48] Khan MA, Amin SMR, Alam N, Tania M. Study of Mycelial Growth of Cordycepssinensis on Different Culture Media. Bangladesh J Mushr2008; 2: 43-48.

[49] Wasser SP, Weis AL. Medicinal properties of substances occurring in Higher Basidiomycetes mushrooms: current perspectives. Int J Med Mushr 1999; 1:31-62.

[50] Bae J-S, Park JW, Park SH, Park JB, Rho Y-H, Ryu YB, Lee K-S, Park K-H, Bae Y-S. Apoptotic cell death of human leukaemia U937 cells by ubiquinone-9purified fromPleurotus eryngii. Nat Product Res 2009; 23(12): 1112-1119. 
[51] Lv H, Kong Y, Yao Q, Zhang B, Leng FW,Bian HJ, Balzarini J, Damme EV, Bao JK. Nebrodeolysin,a novel haemolytic protein from mushroom Pleurotus nebrodensis with apoptosisinducing and anti-HIV-1effects. Phytomedicine 2009;16: 198205.

[52] Li YR, Liu QH, Wang HX, Ng TB. A novel lectin with potent antitumor, mitogenic and HIV-1 reverse transcriptase inhibitory activities from the edible mushroom Pleurotus citrinopileatus. Biochim Biophys Acta 2008; 1780: 51-57.

[53] El Enshasy HA, Hatti-Kaul R. Mushroom immunomodulators:unique molecules with unlimited applications. Trends in Biotechnol 2013; 31(12): 668-677.

[54] Borchers AT, Krishnamurthy A, Keen CL, Meyers FJ, Gershwin ME. The immunobiology of mushrooms. Exp Biol Medicine2008; 233: 259-276.

[55] Chen J, Seviour R. Medicinal importance of fungal $\beta-(1-3)$, (1-6)-glucans. Mycological res 2007; 111: 635-652.

[56] Khan MA, Tania M. Nutritional and Medicinal Importance of Pleurotus Mushrooms: An Overview. Food Rev Inter 2012; 28(3): 313-329.

[57] Gao W, Sun Y, Chen S, Zhang J, Kang J, Wang Y, Wang H, Xia G, Liu Q, Kang Y. Mushroom lectin enhanced immunogenicity of HBV DNA vaccine in C57BL/6 and HBsAg-transgenic mice. Vaccine 2013; 31: 2273- 2280.

[58] Pérez-Martínez AS, Acevedo-Padilla SA, Bibbins-Martínez M, Galván-Alonsoa J, Rosales-Mendoza S. A perspective on the use of Pleurotus for the development of convenient fungimade oral subunit vaccines. Vaccine 2015; 33: 25-33.

[59] Schepetkin IA, Quinn MT.Botanical polysaccharides: Macrophage immunomodulation and therapeutic potential. Int Immunopharmacol 2006; 6: 317 - 333.

[60] Mizuno T, Saito H, Nishitoba T, Kawagashi H. Antitumoractive substances from mushrooms. Food Rev Int $1995 ; 11: 23-61$.

[61] Lindequist $U$, Niedermeyer TH, Julich WD. The pharmacological potential of mushrooms.Evid Based Complement Alternat Med2005;2: 285-299.

[62] Chihara G, Hamuro J, Maeda Y, Arai Y, FukuokaF. Fractionation and purification of the polysaccharides with marked antitumor activity, especially lentinan, from Lentinus edodes(Berk.) Sing.(an edible mushroom). Cancer Res 1970; 30:2776-2781.

[63] Chihara G. Immunopharmacology of lentinan, a polysaccharide isolated from Lentinus edodes: its applications as ahost defence potentiator. Int J Orient Med 1992;17: 57-77.

[64] Tsukagoshi S, Hashimoto Y, Fujii G, Kobayashi H, Nomoto K, OrituK. Krestin(PSK).Cancer Treatment Rev 1984; 11:131135.

[65] Kobayashi H, Matsunaga K, Oguchi Y. Antimetastatic effects of PSK (Krestin), a protein-bound polysaccharide obtained from basidiomycetes: an overview. Cancer Epidemiol Biomark Prevention 1995; 4: 275-281.

[66] Yang QY, Hu YJ, Li XY.A New Biological Response Modifier - PSP. In: ShT Chang, JA Buswell, S W Chiu, eds. Proceedings of the First International Conference on
Mushroom Biology and Mushroom Products. Hong Kong. 1993; p. 247-259.

[67] Lavi I, Levinson D, Peri I, Tekoah Y, Hadar Y, SchwartzY .Chemical characterization, antiproliferative properties of polysaccharides extracted from Pleurotus pulmonarius mycelium and fruiting bodies. Appl Microbiold Biotechnol 2010; 85(6):1977-1990.

[68] Wasonga CGO,SheilaAO,JosephCM, CharlesOAO.Mushroompolysaccharideextractsdelayprogressi onofcarcinogenesisinmice. J Exper Therapeut Oncology 2008; 7: $147-152$.

[69] Akanni EO, Oloke JK, Adebayo EA, Ola IO. Antitumour activities of Pleurotus pulmonarius and Pleurotus ostreatus metabolites on N-Nitroso-N-ethylurea induced solid tumour bearing Wister rats. Glob Res J2010; 1(1): 013- 018.

[70] Sun Y, Liu J. Purification, structure and immunobiological activity of a water-solublepolysaccharide from the fruiting body of Pleurotus ostreatus. Biores Technol 2009; 100: 983986.

[71] Zhang M, Zhu L, Cui SW, Wang Q, Zhou T, Shen H. Fractionation, partial characterization and bioactivity of water-soluble polysaccharides and polysaccharide-protein complexesfromPleurotus geesteranus. Int $\mathrm{J}$ Biol Macromol2011; 48: 5-12.

[72] Facchini JM, Endi PA, Charlise A, Regina MMG, Marcia LLS Wisbeck E, Sandra AF. Antitumor activity of Pleurotus ostreatus polysaccharide fractions on Ehrlich tumor and Sarcoma 180. IntJ Biol Macromol 2014; 68: 72-77.

[73] Patel Y, Ram N, Singh VK.Medicinal Properties ofPleurotus species (Oyster Mushroom): A Review. World J Fungal Plant Biol 2012; 3(1): 01-12.

[74] Choi DB, Cha WS, Kang SH, Lee BR.Effect of Pleurotus ferulae Extracts on Viability of Human Lung Cancer and Cervical Cancer Cell Lines. Biotechnol. Bioprocess Eng 2004; 9: 356-361.

[75] Vos AP, M'Rabet L, Stahl B, Boehm G, Garssen J. Immunemodulatory effects and potential working mechanisms oforally applied nondigestible carbohydrates. Crit Rev Immunol 2007; 27: 97-140.

[76] Batbayar S, Lee DH, Kim HW. Immunomodulation of Fungal $\beta$-Glucan in Host Defense Signaling by Dectin-1.Biomol Ther 2012; 20(5): 433-445.

[77] Schmid F, Stone BA, McDougall BM, Bacic A, Martin KL, Brownlee RT, Chai E, Seviour RJ. Structure of epiglucan, a highly side-chain/branched $(1 \rightarrow 3 ; 1 \rightarrow 6)-\beta$-glucan from themicro fungus Epicoccum nigrum Ehrenb.ex Schlecht. Carbohydrate Res 2001; 331: 163-171.

[78] McIntosh M, Stone BA, Stanisich VA. Curdlan and other bacterial $(1 \rightarrow 3)-\beta$-D-glucans. Appl Microbiol Biotechnol 2005; 68: 163-173.

[79] Seviour RJ, Stasinopoulos SJ, Auer DPF. Production of pullulan and other exopolysaccharides by filamentous fungi. Critical Rev Biotechnol 1992; 12: 279-298.

[80] Klis FM, de Groot P, Hellingwerf K. Molecular organization of the cell wall of Candida albicans. Medical Mycol 2001; 39: $1-8$. 
[81] Jayus, McDougall BM, Seviour RJ. Purification and characterization of the $(1 \rightarrow 3)$ - $\beta$-glucanases fromAcremoniumsp.IMI 383068.FEMS Microbiol Lett 2004; 230: $259-264$.

[82] Martin KL, McDougall BM, Unkles SE, Seviour RJ. The three $\beta$-1,3-glucanases from Acremonium blochiistrain C59 appear tobe encoded by separate genes. Mycological Res 2006; 110: 66-74.

[83] Vetvicka V, Yvin JC. Effects of marine $\beta-1,3$ glucan onimmune reactions. Inter Immunopharmacol 2004; 4:721730 .

[84] Brown GD, Gordon S. Immune recognition of fungal $\beta$ glucans. Cellular Microbiol 2005; 7: 471-479.

[85] Kurashige S, Akuzawa Y, Endo F. Effects ofLentinus edodes, Grifola frondosa and Pleurotus ostreatus administration on cancer outbreak, and activities of macrophages and lymphocytesin mice treated with a carcinogen, N-butyl-Nbutanolnitrosoamine. Immunopharmacol Immunotoxicol 1997; 19: $175-183$.

[86] Brown GD, Taylor PR, Reid DM, Willment JA, Williams DL, Martinez-Pomares L, Wong SY, Gordon S. Dectin-1 is a major $\beta$-glucan receptor on macrophages. J Exper Medicine 2002; 196: 407-412.

[87] Munz C, Steinman RM, Fujii S. Dendritic cell maturation byinnate lymphocytes: coordinated stimulation of innate and adaptive immunity. J ExperMedicine2005; 202:203-207.

[88] Vetvicka V, Thornton BP, Ross GD. Soluble $\beta$-glucan polysaccharide binding to the lectin site of neutrophil or naturalkiller cell complement receptor type 3 (CD11b/CD18) generatesa primed state of the receptor capable of mediating cytotoxicity of iC3b-opsonized target cells. J Clinical Investigat I996; 98: 50-61.

[89] Sato M, Sano H, Iwaki D, Kudo K, Konishi M, Takahashi H,Takahashi T, Imaizumi H, Asai Y, Kuroki Y. Direct binding of Toll-like receptor 2 to zymosan, and zymosaninduced NFkappa $\mathrm{B}$ activation and TNF- $\alpha$ secretion are down-regulated by lung collecting surfactant protein A. J Immunol 2003; 171: $417-425$.

[90] Young RE, Thompson RD, Larbi KY, La M, Roberts CE, Shapiro SD,Perretti M, Nourshargh S. Neutrophil elastase (NE)-deficient mice demonstrate a nonredundant role for NE inneutrophil migration, generation of proinflammatory mediators, and phagocytosis in response to zymosan particles in vivo. J Immunol 2004; 172: 4493-4502.

[91] Du Z, Kelly E, Mecklenbrauker I, Agle L, Herrero C, Paik P, Ivashkiv LB. Selective regulation of IL-10 signaling andfunction by zymosan.J Immunol.2006; 176: 4785-4792.

[92] Brown GD. Dectin-1: a signalling non-TLR patternrecognition receptor. Nature Rev Immunol 2006; 6: 33-43.

[93] Zhang M, Zhang L, Wang Y, Cheung PC. Chain conformation of sulfated derivatives of beta-glucan from sclerotia ofPleurotus tuber-regium. Carbohydr Res 2003; 338: $2863-$ 2870 .

[94] Manzi P, Pizzoferrato L. Beta-glucans in edible mushrooms. Food Chem 2000;68:315-318.

[95] Bergendiova K, Tibenska E, Majtan J. Pleuran ( $\beta$-glucan from Pleurotus ostreatus) supplementation, cellular immune response and respiratory tract infections in athletes. Eur $\mathrm{J}$
ApplPhysiol 2011; 111: 2033-2040.

[96] Bobovčák M, Kuniaková R, Gabriž J, Majtán J. (2010) Effect of pleuran ( $\beta$-glucan from Pleurotus ostreatus) supplementation on cellular immune response after intensive exercise in elite athletes. Appl Physiol Nutr Metab 2010; 35: 755-762.

[97] Rovensky J,Stanckova M. Svi'k K, Bauerova' K, Jurcovicova $J$. The effects of $\beta$-glucan isolated from Pleurotus ostreatus on methotrexate treatment in rats with adjuvant arthritis. Rheumatol Int 2011; 31:507-511.

[98] Jedinak A, Shailesh D, Qing-li W, James S, Daniel S (2011). Anti-inflammatory activity of edible oyster mushroom is mediated through the inhibition of NF-қB and AP-1 signaling. Nutr J 2011; 52: 1-10.

[99] Pramanik M, Mondal S,Chakraborty I, Rout D, Islam SS. Structural investigation of a polysaccharide (Fr. II)isolated from the aqueous extract of an edible mushroom, Pleurotus sajor-caju. Carbohydr Res 2005; 340: 629-636.

[100] Kamilya D,Ghosh D, Bandyopadhyay S, Mal BC, Maiti TK. In vitroeffects of bovine lactoferrin, mushroom glucan and Abrus agglutinin on Indian major carp, catla(Catla catla) head kidney leukocytes. Aquacult 2006; 253: 130-139.

[101] Zhang X, Zhang L, Xu X. Morphologies and conformation transition of Lentinan in aqueous $\mathrm{NaOH}$ solution. Biopolymers 2004; 75: 187-195.

[102] Lin WH, Hung CH, Hsu CI, Lin JY. Dimerization of the Nterminalamphipathic alpha-helix domain of the fungal immunomodulatory protein from Ganoderma tsugae (Fip-gts) defined by ayeast two-hybrid system and site-directed mutagenesis. J BiolChem 1997; 272: 20044-20048.

[103] Hsu HC, Hsu CI, Lin RH, Kao CL, Lin JY. Fip-vvo, a new fungal immunomodulatory protein isolated from Volvariella volvacea. Biochem J 1997;323(Pt 2):557-565.

[104] Paaventhan P, Joseph JS, Seow SV, Vaday S, Robinson H, Chua KY. A 1.7 A structure of Fve, a member of the new fungal immunomodulatory protein family. $\mathrm{J}$ Mol Biol 2003;332: 461-470.

[105] Ko JL, Hsu CI, Lin RH, Kao CL, Lin JY. A new fungal immunomodulatory protein, FIP-fve isolated from the ediblemushroom,Flammulina velutipesand its complete amino acidsequence. Eur J Biochem 1995; 228:244-249.

[106] Adebayo EA, Oloke JK, Achana Y, Bora TC. Improvement ofLaccase Production in Pleurotus pulmonarius-LAU 09 by Mutation. J Microbiol Res 2012a; 2(1): 11-17.

[107] Chen J-N, Wang Y-T,Wu JS-B.A Glycoprotein Extracted from Golden Oyster Mushroom Pleurotus citrinopileatus Exhibiting Growth Inhibitory Effect against U937 Leukemia Cells. J Agric Food Chem 2009; 57: 6706-6711.

[108] Wu J-Y,Chen C-H, Chang W-H, Chung K-T, Liu Y-W,Lu FJ,Chen C-H. Anti-Cancer Effects of Protein Extracts from Calvatia lilacina, Pleurotus ostreatu sand Volvariella volvacea. Evidence-Based Compl Alter Medicine 2011; doi:10.1093/ecam/neq057.

[109] Nomura H, Inokuchi N, Kobayashi H, Koyama T, Iwama M, Ohgi K. Purification and primary structure of a new guanylic and specific ribonuclease from Pleurotus ostreatus. J Biochem 1994;116:26-33. 
[110] Wong JH, Ng TB, Jiang Y, Liu F, Sze SCW, Zhang KY. Purification and Characterization of a Laccase with Inhibitory Activity Toward HIV-1 Reverse Transcriptase and Tumor Cells from an Edible Mushroom (Pleurotus cornucopiae). Prot Pept Lett 2010; 17: 1040-1047.

[111] Wang HX, Ng TB, Ooi VEC.A ribonuclease from sclerotia of the edible mushroom Pleurotus tuber-regium. Biochem Biophys Res Commun 1998;250:544-546.

[112] Wang HX, Ng TB. Isolation and characterization of velutin, a novel low-molecular-weight ribosome-inactivating protein from winter mushroom (Flammulina velutipes) fruiting bodies. Life Sci 2001; 68: 2151-2158.

[113] Wang JB, Wang HX, Ng TB.A peptide with HIV-1 reverse transcriptase inhibitory activity from the medicinal mushroom Russula paludosa. Peptides 2007;28(3): 560-565.

[114] Maiti S, Bhutia SK, Mallick SK, Kumar A, Khadgi N, Maiti TK. Antiproliferative and immunostimulatory protein fraction from edible mushrooms. Environ Toxicol Pharmacol 2008;26(2):187-191.

[115] Peumans WJ,Zhang W,Barre A, Houles CA, Balint-Kurti PJ, Rovira P, Rouge P, May GD, Van LF, Truffa-Bachi P, Van Damme EJM. Fruit-specific lectins from banana and plantain. Planta 2000; 211(4): 546-554.

[116] Loris R, Hamelryck T, Bouckaert J, Wyns L. Legume lectin structure. Biochim et Biophys Acta 1998; 1383(1): 9-36.

[117] She Q-B, Ng T-B, Liu W-K.A novel lectin with potent immunomodulatory activity isolated from both fruiting bodies and cultured mycelia of the edible mushroom Volvariella volvacea. Biochem Biophys Res Comm 1998; 247(1): 106111 .

[118] Wang H, Gao J, Ng T. A new lectin with highly potent antihepatoma and antisarcoma activities from the oyster mushroom Pleurotus ostreatus. BiochemBiophys Res Commun 2000;275(3):810-816.

[119] Wang HX, Ng TB, Liu WK, Ooi VEC, Chang ST. Isolation and characterization of two distinct lectins with antiproliferative activity from the cultured mycelium of the edible mushroomTricholoma mongolicum. Int JPeptide Protein Res 1995; 46: 508-513.

[120] Wang HX, Ng TB, Ooi VEC, Liu WK, Chang ST.A polysaccharide-peptide complex from cultured mycelia of themushroom Tricholoma mongolicumwith immunoenhancing and antitumor activities.Biochem Cell Biol 1996; 74: 95-100.

[121] Li YR, Zhang GQ, Ng TB, Wang HX. A novel lectin with antiproliferative and HIV-1reverse transcriptase inhibitory activities from dried fruiting bodies of themonkey head
mushroomHericium erinaceum. J Biomed Biotechnol 2010; doi:10.1155/2010/716515.

[122] Rana T, Asit KB, Subhashree D, Debasis B, Diganta P,Samiran B, Dipak KM, Srikanta S, Subhasish B, Subrata KD. Pleurotus floridalectin normalizes duration dependent hepatic oxidative stressresponses caused by arsenic in rat. Exper Toxicologic Pathol 2012; 64: 665-671.

[123] Mostafavi H, Mohammad-Fata M, Shirin G, Ghorban-Ali H. Immunomodulating and anticancer agents in the realm ofmacromycetes fungi (macrofungi). Int Immunopharmacol 2007; 7 : 701-724.

[124] Ivanova TS, Krupodorova TA, Barshteyn VY, Artamonova AB, Shlyakhovenko VA.Anticancer Substances of Mushroom Origin.Exp Oncol 2014; 36(2): 58-66.

[125] Bok JW, Lermer L, Chilton J.Antitumor sterols fromthe mycelia of Cordyceps sinensis. Phytochem 1999; 51: 891-898.

[126] Jedinak A, Sliva D. Pleurotus ostreatus inhibits proliferation of human breast and colon cancer cells through p53dependent as well as p53-independent pathway. Int J Oncol 2008; 33(6): 1307-1313.

[127] Martin KR, Brophy SK. Commonly consumed and specialty dietary mushrooms reducecellular proliferation in MCF-7 human breast cancer cells. Exper Biol Medicine2010;235: $1306-1314$.

[128] Jedinak A, Dudhgaonkar S, Jiang J, Sandusky G, Sliva D. Pleurotus ostreatusinhibits colitis-relatedcolon carcinogenesis in mice. Inter J Molecul Medicine 2010; 26: 643-650.

[129] Gu YH, Leonard J. In vitro effects on proliferation, apoptosis and colony inhibition in ER-dependent and ER-independent human breast cancer cells by selected mushroom species. Oncol Rep2006;15:417-423.

[130] Kim JH, Kim SJ, Park HR, Choi JI, Ju YC, Nam KC, Kim SJ, Lee SC. The different antioxidant and anticancer activities depending on the color of oyster mushrooms. J Med Plants Res 2009; 3: 1016-1020.

[131] Takei T, Yoshida MB, Ohnishi-Kameyama M. Ergosterol peroxide, an apoptosis-inducing component isolated from Sarcodon aspratus (Berk.) S. Ito. Biotech Biochem2005; 69: 212-215.

[132] Liu Y-W, Mei H-C, Su Y-W, Fan H-T, Chen C-C, Tsai Y-C. Inhibitory effects of Pleurotus tuber-regium mycelia and bioactive constituents on LPS-treated RAW264.7 cells. J Functional Foods 2014; 7: 662-670. 